Pak. j. sci. ind. res. Ser. B: biol. sci. 201255 (2) 70-81

\title{
Decomposition and Nutrients Release Pattern of Leaves, Stems / Vines and Roots of Selected Leguminous and Non-Leguminous Plant Species
}

\author{
Oladele Abdulahi Oguntade a , Abideen Idowu Adeogun ${ }^{\mathrm{b} *}$, \\ Guogiong Tian' ${ }^{\mathrm{c}}$ and Gideon Adeoye ${ }^{\mathrm{d}}$ \\ ${ }^{a}$ Soil Science Department, University of Agriculture, Abeokuta, Nigeria \\ ${ }^{\mathrm{b} C h e m i s t r y ~ D e p a r t m e n t, ~ U n i v e r s i t y ~ o f ~ A g r i c u l t u r e, ~ A b e o k u t a, ~ N i g e r i a ~}$ \\ ${ }^{c}$ Environmental Monitoring and Research Division, Research and Development Department, \\ Metropolitan Water Reclamation District of Greater Chicago (MWRD-Chicago), \\ Lue-Hing R\&D Complex, 6001 W. Pershing Road, Cicero, IL 60804, USA \\ ${ }^{\mathrm{d} A g r o n o m y ~ D e p a r t m e n t, ~ U n i v e r s i t y ~ o f ~ I b a d a n, ~ I b a d a n, ~ N i g e r i a ~}$
}

(received November 28, 2011; revised April 12, 2012; accepted May 2, 2012)

\begin{abstract}
Decomposition and nutrients release pattern of leaves, stems/vines and roots of leguminous plants (Pueraria phaseoloides and Centrosema brasilianum) and non-leguminous plants (Chromolaena odorata and Panicum maximum) were examined for a period of 98 days. The decomposition rate declined in the order $P$. maximum $>C$. odorata $>$ P. phaseoloides $>C$. brasilianum. On the $98^{\text {th }}$ day, between $63 \%$ and $71 \%$ of stems/vines only had decomposed. The $\%$ mass of the remaining materials were in the order of $C$. odorata $>$ P. phaseoloides $>C$. brasilianum $>$ P. maximum and the decomposition rate was in the reverse order. The mass loss and decomposition rates of the parts of the plant species followed the initial $\mathrm{N}$ concentrations of the residues in the order of leaves $>$ roots $>$ stems/vines. The initial $\mathrm{N}$ contents in plant residues varied from 0.42 to $3.19 \mathrm{~g} / \mathrm{kg}$ and $P$ from 0.03 to $0.27 \mathrm{~g} / \mathrm{kg}$. The pattern of $\mathrm{N}$ remaining in the stems/vines of the species at 98 days after placements (DAP) was in the order P. phaseoloides (49\%) $>$ C. odorata $(42 \%)>C$. brasilianum $(41 \%)>P$. maximum $(36 \%)$. The chemical composition of the residues shows that the leaves are richer in $\mathrm{N}$ and $\mathrm{P}$ than the roots and least in stems/vines in the order $C$. odorata $>C$. brasilianum $>$ P. phaseoloides $>P$. maximum. A direct relationship was observed between the initial $\mathrm{N}$ contents of the residues and initial polyphenol contents $(\mathrm{r}=0.72, \mathrm{p}<0.01)$, but no relationships with the $\mathrm{P}$ content of the residues. The data reported in this study shows that the decomposition patterns of above and below - ground residues of leguminous and non-leguminous plant species could have positive effect on nutrients requirement of crops.
\end{abstract}

Keywords: nutrients release, plant decomposition, non-leguminous, Pueraria phaseoloides, Centrosema brasilianum, Chromolaena odorata, Panicum maximum

\section{Introduction}

In agroforestry systems, plant residues enter the soil system as crop residues and tree leaf litter and pruning residues. These plant residues are sources of nutrients and organic matter when they decompose and could contribute to the maintenance of soil fertility. The use of plant residues to improve crop production has become a major focus of soil fertility management in the tropics (Tian, 1998). Thus, bio-availability of nutrients is a function of nutrients supply and nutrients limitation, which in turn depend on differences in the rate of decomposition, mineralization and other processes (Swift et al., 1979). Residue management for nutrients recycling involves synchronizing nutrients release with

*Author for correspondence; E-mail: abuaisha2k3@yahoo.com crop demands. This could be achieved by manipulating the nutrients release pattern of the residues through appropriate timing and placement of organic input to meet crop use (Myers et al., 1994). For instance, incorporating plant residues into agricultural soils can sustain organic carbon (C) content, improve soil physical properties, enhance biological activities, and increase nutrient availability (Zeng et al., 2010; Cayuela et al., 2009; Hadas et al., 2004).

Residue decomposition rates and nutrient release patterns are controlled by both biotic and abiotic factors, the most important of which is residue quality (Zeng et al., 2010; Teklay et al., 2007; Mungai and Motavalli, 2006; Silver and Miya, 2001). The initial concentrations of nitrogen $(\mathrm{N})$, phosphorus $(\mathrm{P})$, polyphenol and lignin, 
and the ratios of $\mathrm{C} / \mathrm{N}$, lignin $/ \mathrm{N}$ and polyphenol/ $\mathrm{N}$ are generally recognized as the main litter quality variables controlling rates of decomposition (Zeng et al., 2010; Liu et al., 2007; Teklay et al., 2007; Raiesi, 2006; Silver and Miya, 2001; Mafongoya et al., 2000). The immobilization of nutrients during decomposition often results in reduction of soil nutrients availability and also lowers nutrients losses (Gómez Rey et al., 2008).

Understanding the regulatory mechanism of decomposition and nutrients release of below and above ground organic input is necessary for the prediction of mass loss and nutrients release pattern in agro-ecosystem. Since agroforestry systems contain a mixture of plant species such as trees and crops that have different growth forms and residue qualities, their mixed residues therefore, may not decompose in a similar pattern to their individual components. Because of management practices such as on-site retention of straw and tillage, residues of trees and crops usually become mixed and decompose simultaneously within the same soil volume. Interactive effects of residue mixtures on decomposition may occur when residues of component species with contrasting residue quality are mixed (Zeng et al., 2010; Hoorens et al., 2002). For example, in tropical agroforestry systems, mixing residues of trees and crops with different qualities can potentially be used to manipulate residue decomposition and regulate the timing of nutrients availability (Zeng et al., 2010; Sakala et al., 2000). Decomposition of organic matter in the soil is intrinsically heterogeneous, because a number of compounds of different characteristics and qualities are present in the original material and are produced during the decay process (Berg et al., 1982).

The decomposition process depends on a range of agroecological factors such as temperature, precipitation, soil moisture, available nutrients and biological activity of the soil. The nutrients released from decomposing residues are important stage of nutrient cycle in terrestrial ecosystem that influences primary productivity. Plant nutrients are released from litter by both, the physical leaching and break down of structural organic components by soil organisms. Elements are retained to different extent in decomposing litters by microbial immobilization. Therefore, the dynamics of a single element depends on its status as a limiting or nonlimiting nutrient for microbial growth (Swift et al., 1979; Parnas, 1975; Gosz et al., 1973). Elements in limiting concentration are retained in the litter up to certain critical concentration and then released at the same rate as the organic matter decreased (Berg and Staaf, 1981). Nutrients release is determined by leaf weight loss and change in nutrients concentration in the decomposing leaves (Tian, 1998). Risasi et al. (1998) reported that $\mathrm{N}$ release pattern of decomposing roots is the same as dry-matter loss. As a part of study on regeneration of degraded soil by plant biomass under tropical climates, this study reports the decomposition and nutrients release pattern of leaves, stems/vines and roots of selected leguminous and non-leguminous plants.

\section{Materials and Methods}

Site location and plant materials. The decomposition study was carried out between July and November, at West Bank (WB) III block of International Institute of Tropical Agriculture (IITA), Ibadan, Nigeria. Residues of Pueraria phaseoloides and Centrosema brasilianum were used as leguminous plant while Chromolaena odorata and Panicum maximum were used as nonleguminous plants. The experiment was conducted on an on-going long term fallow management trial. Natural bush crop fallow (NF) and Pueraria phaseoloides crop fallow (PF) cycles with a year of cropping followed by a year fallow were used. The plots were under maize/cassava crop when trial was conducted.

Preparation of plant materials. Leaves, stems/vines and roots of matured plants of the plant species used were collected and air dried in the screen house prior to application. The stems/vines were cut into $10 \mathrm{~cm}$ size for easy placement in the litterbags. Sub samples were taken and oven dried at $65{ }^{\circ} \mathrm{C}$ for $48 \mathrm{~h}$ for dry matter determination. The dried samples were ground, sieved with $0.85 \mathrm{~mm}$ diameter sieve and analyzed for their chemical composition.

Experimental procedure. The site was laid out in a split plot arrangement in a randomized complete block design with four replications. The main plot size was $6 \times 9 \mathrm{~m}$, while the subplots were $6 \times 4 \mathrm{~m}$, totaling 24 subplots (Table 1). Forty five gram of dry matter per hectar or 5 tons of dry matter per hectare, (i.e. root, stem/vine and leaves of these plants) were placed as mulch material in $5 \mathrm{~mm}$ mesh size litterbags measuring $30 \times 30 \mathrm{~cm}$. Litterbags containing shoot residues (leaves, stem/vine) were surface placed while those with root were buried at $5 \mathrm{~cm}$ depth in an established maize (Zea mays L.) - cassava (Manihot esculenta Crantz) trial on $\mathrm{NF}$ and PF plots. Leguminous residues were placed on the plot under PF while non-leguminous residues were placed on the plot under NF prior to cropping. A total 
Table 1. Layout of the experimental site

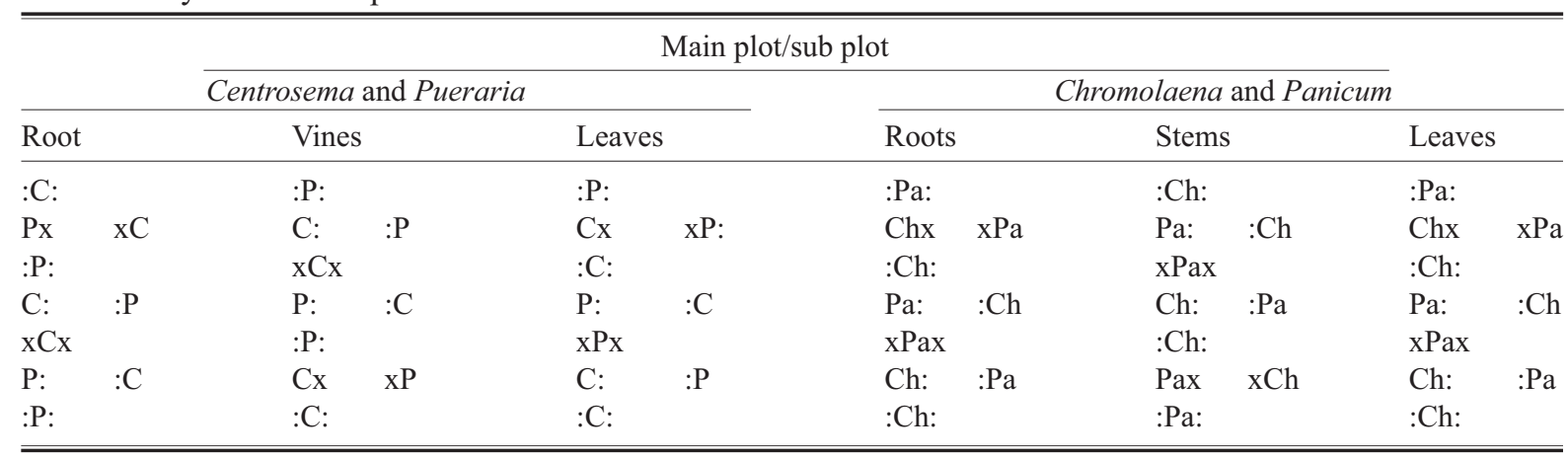

$\mathrm{P}=$ Pueraria $; \mathrm{C}=$ Centrosem $;$, $\mathrm{Ch}=$ Chromolaena $; \mathrm{Pa}=$ Panicum $;:=$ Maize stand $; \mathrm{x}=$ Cassava stand.

of 240 litterbags were used and each replicate had 30 litterbags, so that each treatment could be sampled five times. Forty eight litterbags were retrieved randomly at $0,5,12,21,42$ and 98 days after placement. The residues in the litterbags were collected for dry matter determination and chemical composition analysis.

Soil analysis. The soil $\mathrm{pH}$ was determined using soil distilled water ratio of 1:2. Total organic carbon (C) was determined by wet combustion. Total nitrogen (N) was analyzed by micro Kjeldahl digestion followed by distillation titration (Tian et al., 2007). Available phosphorus $(\mathrm{P})$ in the soil was measured using the Oslen method as modified by Okalebo et al. (1993). Exchangeable cations were extracted from soil by $1 \mathrm{~N}$ ammonium acetate $\left(\mathrm{NH}_{4} \mathrm{OAc}\right)$. Total calcium $(\mathrm{Ca})$ and magnesium $(\mathrm{Mg})$ were by nitroperchloric digestion and measured by atomic absorption spectrophotometer (EMBRAPA, 1999) and determined using atomic absorption spectroscopy (AAS) while potassium (K) was determined by flame photometer. The microbial $\mathrm{C}$ and $\mathrm{N}$ of the soil was measured by the fumigation-extraction method of Amato and Ladd (1988) as modified by Joergensen and Brooks (1990). Ash free dry weight was determined by ashing the plant samples in a muffle furnace at $550{ }^{\circ} \mathrm{C}$ for $3 \mathrm{~h}$.

Plant analysis. Total $\mathrm{N}, \mathrm{Ca}$ and $\mathrm{Mg}$ and $\mathrm{K}$ were determined as explained above. $\mathrm{P}$ was determined colorimetrically by the molybdate blue method in an auto-analyzer (Zeng et al., 2010). Lignin, cellulose and hemi-cellulose content were determined by the acid detergent fibre method (Van Soest and Wine, 1968).

Data analysis. The decomposition rate constant $(k)$. The decomposition rate constant $(\mathrm{k})$ was estimated using the Wieder and Lang (1982) first order single exponential equation:

$$
\mathrm{L}_{\mathrm{R}} / \mathrm{L}_{\mathrm{I}}=\mathrm{e}^{-\mathrm{kt}}
$$

where, $L_{R}$ is the weight of litter at a given time, $L_{I}$ is the initial litter weight at $t=0, t$ is the time interval of sampling, $\mathrm{k}$ is the decomposition rate constant.

Nutrients released rate. Nutrients released over time by the organic matter were calculated using the formula by Giashuddin et al. (1993) with the following equation:

$$
\% \mathrm{~N}_{\mathrm{R}}=100-\% \mathrm{~W} . .
$$

where, $\mathrm{N}_{\mathrm{R}}$ is the nutrients released, $\mathrm{W}$ is the original nutrients content remaining. The original nutrients were determined using equation:

$$
\% \mathrm{~N}_{\mathrm{O}}=\frac{\% \mathrm{w}_{\mathrm{t}} \times \% \mathrm{~W}}{\% \mathrm{w}_{0}}
$$

where, $\mathrm{N}_{\mathrm{O}}$ is the original nutrients, $\mathrm{w}_{0}$ and $\mathrm{w}_{\mathrm{t}}$ are remaining nutrients after time 0 and time $t$, respectively.

Decomposition and nutrients release patterns. Ash free weight of the remaining plant materials and decomposition rate constants were subjected to ANOVA, to determine difference in decomposition and nutrients release patterns of different parts of the studied leguminous and non-leguminous plant species. Earthworms number was normalized by $\log _{10}(\mathrm{x}+1)$ transformation and fresh earthworm weight was transformed by square root before ANOVA (Tian et al., 2000). The biomass ninhydrin- $\mathrm{N}\left(\mathrm{B}_{\mathrm{NRN}}\right)$, biomass $\mathrm{C}\left(\mathrm{B}_{\mathrm{c}}\right)$, and biomass $\mathrm{N}$ $\left(B_{N}\right)$ were estimated according to the following relations (Joergensen and Brooks, 1990; Amato and Ladd, 1988; Shen et al., 1984):

$$
\mathrm{B}_{\mathrm{NRN}}=\mathrm{NRN}_{\mathrm{f}}-\mathrm{NRN}_{\mathrm{n}}
$$

where, $\mathrm{NRN}_{\mathrm{f}}$ is the ninhydrin-N extracted from 
fumigated soil, $\mathrm{NRN}_{\mathrm{n}}$ is the ninhydrin-N extracted from unfumigated soil:

$$
\begin{aligned}
& \mathrm{B}_{\mathrm{c}}=21 \times \mathrm{B}_{\mathrm{NRN}} . \\
& \mathrm{B}_{\mathrm{N}}=3.1 \times \mathrm{B}_{\mathrm{NRN}}
\end{aligned}
$$

\section{Results and Discussion}

Soil properties of the study area. The soil properties of the studied area are presented in Table 2. The $\mathrm{pH}$ ranged from slightly acidic to neutral $(6.2-7.0)$. Organic $\mathrm{C}$ and total $\mathrm{N}$ contents were moderate. Available $\mathrm{P}$ was low, exchangeable $\mathrm{K}, \mathrm{Ca}$, and $\mathrm{Mg}$ were also low for both PF and NF plots. The textural class of the NF plot ranged from loamy sand in the upper $0-5 \mathrm{~cm}$ to sandy soil at $5-15 \mathrm{~cm}$ depth. The PF plot on the other hand had loamy and sand texture at both soil depths.

Table 3 shows the effect of residue parts on soil chemical properties of the site after the decomposition study. The leaves, vines and roots of leguminous plant species were of the same effect on the soil chemical properties. For the non-leguminous plant species, C. odorata leaf, stem and root did not affect the soil $\mathrm{pH}$, available $\mathrm{P}$ and exchangeable $\mathrm{K}$ differently. The effect of the parts of the species on the soil organic $\mathrm{C}$, total $\mathrm{N}$ and exchangeable $\mathrm{Mg}$ were in the order of leaves $>$ roots $>$ stems, while the exchangeable $\mathrm{Ca}$ followed the order roots $>$ leaves $>$ stems. There was no difference in the influence of the leaves and roots on the soil properties. P. maximum leaves, stem and root did not affect the soil chemical properties.

Chemical composition of the residue. Chemical compositions of the residues are shown in Table 4 . The $\mathrm{N}$ and $\mathrm{P}$ were found in higher contents in the leaves than roots and least in stems/vines. The $\mathrm{N}$ was in the order of $C$. odorata $>C$. brasilianum $>P$. phaseoloides $>$ $P$. maximum. In $P$. phaseoloides, $C$. odorata and C. brasilianum $\mathrm{P}$ content of the plant parts was in the order of leaves $>$ roots $>$ stems/vines unlike $P$. maximum where it was in the order of leave $>$ stem $>$ root. Exchangeable $\mathrm{K}$ and $\mathrm{Ca}$ in $P$. phaseoloides were higher in the root and least in the leaves. For $C$. odorata, exchangeable $\mathrm{K}$ was highest in root and least in stem, while Ca content was highest in the leaves and least in stems. In P. maximum exchangeable $\mathrm{K}$ and $\mathrm{Ca}$ were in the order of leaf $>$ root $>$ stem. The $\mathrm{Mg}$ content was highest in leaves and least in vines of leguminous residues while it was in the order of stems $>$ leaves $>$ roots in the non-leguminous residues.

The polyphenol content of the leguminous species was in the order of leaves $>$ roots $>$ vines and in the nonleguminous species it was in the order of leaves $>$ stems $>$ roots. A direct relationships was observed between the initial $\mathrm{N}$ contents of the residues and initial polyphenol contents $(r=0.72, p<0.01)$, but no relationships with the $\mathrm{P}$ content of the residues.

The lignin was higher in the stems/vines and least in the leaves for all the species except in $P$. maximum where the least concentration was in the root. The cellulose content followed similar content as the polyphenol content for all plant parts. Correlation analysis showed that the initial cellulose contents of these residues were negatively correlated with initial $\mathrm{N}$ and $\mathrm{P}$ content of the materials $(\mathrm{r}=-0.85, \mathrm{p}<0.01$ for $\mathrm{N}$ and $\mathrm{r}=-0.69, \mathrm{p}<0.05$ for $\mathrm{P}$ ), respectively. Hemicellulose was highest in $P$. phaseoloides leaves but least in the vine, however, the root of C. brasilianum, has higher concentration of hemicellulose while the

\begin{tabular}{|c|c|c|c|c|}
\hline \multirow[t]{2}{*}{ Properties } & Natural fallow & Pueraria fallow & Natural fallow & Pueraria fallow \\
\hline & \multicolumn{2}{|c|}{$(0-5 \mathrm{~cm})$} & \multicolumn{2}{|c|}{$(5-15 \mathrm{~cm})$} \\
\hline $\mathrm{pH}\left(\mathrm{H}_{2} \mathrm{O}\right)(1: 2)$ & 6.9 & 6.7 & 7.0 & 6.2 \\
\hline Organic carbon $(\mathrm{g} / \mathrm{kg})$ & 16.4 & 15.4 & 8.2 & 6.8 \\
\hline Nitrogen $(\mathrm{g} / \mathrm{kg})$ & 1.6 & 1.5 & 0.9 & 0.7 \\
\hline Average phosphorus & 6.2 & 6.2 & 2.9 & 2.1 \\
\hline Potassium $[\mathrm{cmol}(+) / \mathrm{kg}]$ & 0.5 & 0.3 & 0.3 & 0.4 \\
\hline Calcium $[\mathrm{cmol}(+) / \mathrm{kg}]$ & 5.4 & 3.8 & 3.7 & 3.0 \\
\hline Magnesium $[\mathrm{cmol}(+) / \mathrm{kg}]$ & 1.1 & 0.8 & 0.7 & 0.6 \\
\hline Sand $(g / k g)$ & 829.6 & 790.5 & 880.3 & 853.6 \\
\hline Silt (g/kg) & 107.4 & 152.9 & 62.0 & 82.4 \\
\hline Clay $(\mathrm{g} / \mathrm{kg})$ & 63.0 & 56.6 & 57.8 & 63.1 \\
\hline Texture & Loamy sand & Loamy sand & Sand & Loamy sand \\
\hline
\end{tabular}

Table 2. Soil properties of the studied area before the study 
Table 3. Soil properties of the studied area after the study

\begin{tabular}{|c|c|c|c|c|c|c|c|c|c|c|c|c|}
\hline \multirow[t]{2}{*}{ Properties } & \multicolumn{3}{|c|}{ Pueraria } & \multicolumn{3}{|c|}{ Centrosema } & \multicolumn{3}{|c|}{ Chromolaena } & \multicolumn{3}{|c|}{ Panicum } \\
\hline & Leaf & Vine & Root & Leaf & Vine & Root & Leaf & Stem & Root & Leaf & Stem & Root \\
\hline $\mathrm{pH}\left(\mathrm{H}_{2} \mathrm{O}\right)(1: 2)$ & 6.1 & 6.1 & 6.1 & 6.1 & 6.0 & 6.3 & 6.3 & 6.4 & 6.5 & 6.5 & 6.5 & 6.5 \\
\hline Organic carbon $(\mathrm{g} / \mathrm{kg})$ & 5.3 & 6.8 & 5.3 & 5.9 & 5.6 & 5.3 & 8.8 & 5.8 & 8.5 & 8.0 & 6.7 & 6.5 \\
\hline Nitrogen $(g / k g)$ & 0.5 & 0.6 & 0.4 & 0.6 & 0.5 & 0.4 & 0.9 & 0.5 & 0.9 & 2.9 & 0.8 & 0.8 \\
\hline Average phosphorus (mg/kg) & 2.5 & 2.0 & 1.9 & 2.1 & 1.9 & 0.6 & 2.7 & 2.6 & 3.4 & 2.5 & 1.8 & 2.1 \\
\hline Potassium $[\mathrm{cmol}(+) / \mathrm{kg}]$ & 0.9 & 0.5 & 0.5 & 0.4 & 0.4 & 0.5 & 0.7 & 0.7 & 0.6 & 1.1 & 0.7 & 0.6 \\
\hline Calcium $[\mathrm{cmol}(+) / \mathrm{kg}]$ & 2.3 & 2.8 & 2.4 & 3.2 & 2.6 & 3.2 & 4.7 & 3.3 & 5.1 & 4.3 & 3.6 & 3.6 \\
\hline Magnesium $[\mathrm{cmol}(+) / \mathrm{kg}]$ & 0.3 & 0.4 & 0.4 & 0.6 & 0.4 & 0.5 & 0.9 & 0.5 & 0.8 & 0.7 & 0.7 & 0.5 \\
\hline
\end{tabular}

Table 4. Soil properties (chemical composition) of the studied area after the study

\begin{tabular}{|c|c|c|c|c|c|c|c|c|c|c|c|c|}
\hline \multirow[t]{2}{*}{ Properties (\%) } & \multicolumn{3}{|c|}{ Pueraria } & \multicolumn{3}{|c|}{ Centrosema } & \multicolumn{3}{|c|}{ Chromolaena } & \multicolumn{3}{|c|}{ Panicum } \\
\hline & Leaf & Vine & Root & Leaf & Vine & Root & Leaf & Stem & Root & Leaf & Stem & Root \\
\hline Nitrogen & 2.90 & 0.93 & 1.17 & 3.17 & 0.96 & 1.17 & 3.19 & 0.50 & 0.88 & 1.31 & 0.42 & 0.60 \\
\hline Phosphorus & 0.15 & 0.06 & 0.11 & 0.27 & 0.11 & 0.13 & 0.20 & 0.03 & 0.06 & 0.10 & 0.09 & 0.05 \\
\hline Potassium & 2.28 & 4.85 & 6.29 & 2.42 & 3.35 & 1.64 & 1.57 & 0.39 & 3.53 & 2.15 & 1.28 & 1.50 \\
\hline Calcium & 0.27 & 0.31 & 0.40 & 0.40 & 0.30 & 0.34 & 0.41 & 0.06 & 0.24 & 0.13 & 0.04 & 0.07 \\
\hline Magnesium & 0.26 & 0.11 & 0.16 & 0.28 & 0.22 & 0.26 & 0.45 & 0.83 & 0.40 & 0.36 & 0.76 & 0.33 \\
\hline Lignin & 9.72 & 11.22 & 11.14 & 6.36 & 14.92 & 12.58 & 7.46 & 12.18 & 11.64 & 4.60 & 10.66 & 2.16 \\
\hline Polyphenol & 1.39 & 0.45 & 0.58 & 1.61 & 0.53 & 0.56 & 2.90 & 1.63 & 1.15 & 0.91 & 0.45 & 0.38 \\
\hline Cellulose & 26.48 & 45.74 & 43.08 & 28.08 & 44.80 & 41.68 & 12.06 & 52.56 & 40.44 & 35.62 & 46.82 & 32.86 \\
\hline Hemicellulose & 20.74 & 14.72 & 16.18 & 9.47 & 10.66 & 14.12 & 7.44 & 11.04 & 10.38 & 22.90 & 18.78 & 17.56 \\
\hline
\end{tabular}

least concentration was found in the vine. In the nonleguminous residues, C. odorata had highest concentration of hemicellulose in the stems and the least concentration in the leaves. $P$. maximum had highest concentration in the leaves while its root had the least concentration.

Residue decomposition. The residue remaining over time (undecomposed materials) expressed as percentage of the initial amount applied are shown in Fig. 1. There were no significant differences among the species $(\mathrm{p}<$ 0.05 ) tested at any sampling period. At 42 days after placement (DAP), the quantities of undecomposed leaves of the leguminous species were similar but different from that of non-leguminous plant species. C. brasilianum had the highest amount of undecomposed material (53\%), followed by P. phaseoloides (49\%) C. odorata (37\%) and P. maximum (35\%). At $98 \mathrm{DAP}$, C. odorata leaves had decomposed completely. The decomposition rate declined in the order of $P$. maximum $>C$. odorata $>$ P. phaseoloides $>C$. brasilianum. The decomposition of stems/vines was not significantly different for all the plant species throughout the sampling period $(p>0.05)$. At 98 DAP, between $63 \%$ and $71 \%$ of stems/vines only had decomposed. The $\%$ mass of the remaining material were in the order of $C$. odorata
$>$ P. phaseoloides $>C$. brasilianum $>$ P. maximum and the decomposition rate is in the reverse order.

The dry matter loss of $P$. maximum root was rapid within the first 12 DAP, compared with other species. It then followed a similar trend as that of $C$. odorata and C. brasilianum roots from 21 DAP through 98 DAP. C. odorata and C. brasilianum roots had steady decomposition rate from 42 through 98 DAP. P. maximum had the least decomposition rate and this is clearly shown from 42 DAP. At 98 DAP, $43 \%$ of $P$. maximum roots remained whereas in $P$. phaseoloides, $C$. brasilianum and C. odorata. $20 \%, 15 \%$ and $13 \%$ of the root materials, respectively remained. The decomposition constant rate of the root residues were in the order of $C$. odorata $>$ C. brasilianum $>$ P. phaseoloides $>P$. maximum .

Nitrogen release pattern. The $\mathrm{N}$ mineralization pattern of leguminous and non-leguminous plant species were not significantly different $(p<0.05)$ particularly for the leaves over incubation period (Fig. 2). The leaves of the residue showed rapid $\mathrm{N}$ mineralization within the first 12 DAP and afterwards a steady mineralization through 98 days of study (Fig. 2). The N release pattern of the leaves was relatively higher than the total mass loss for most of the corresponding dates except for P. maximum leaf at $98 \mathrm{DAP}$. 
The stems/vines of $P$. phaseoloides and C. odorata showed initial $\mathrm{N}$ immobilization at $12 \mathrm{DAP}$ then followed by increasing net $\mathrm{N}$ mineralization throughout the decomposition period. On the other hand, C. brasilianum
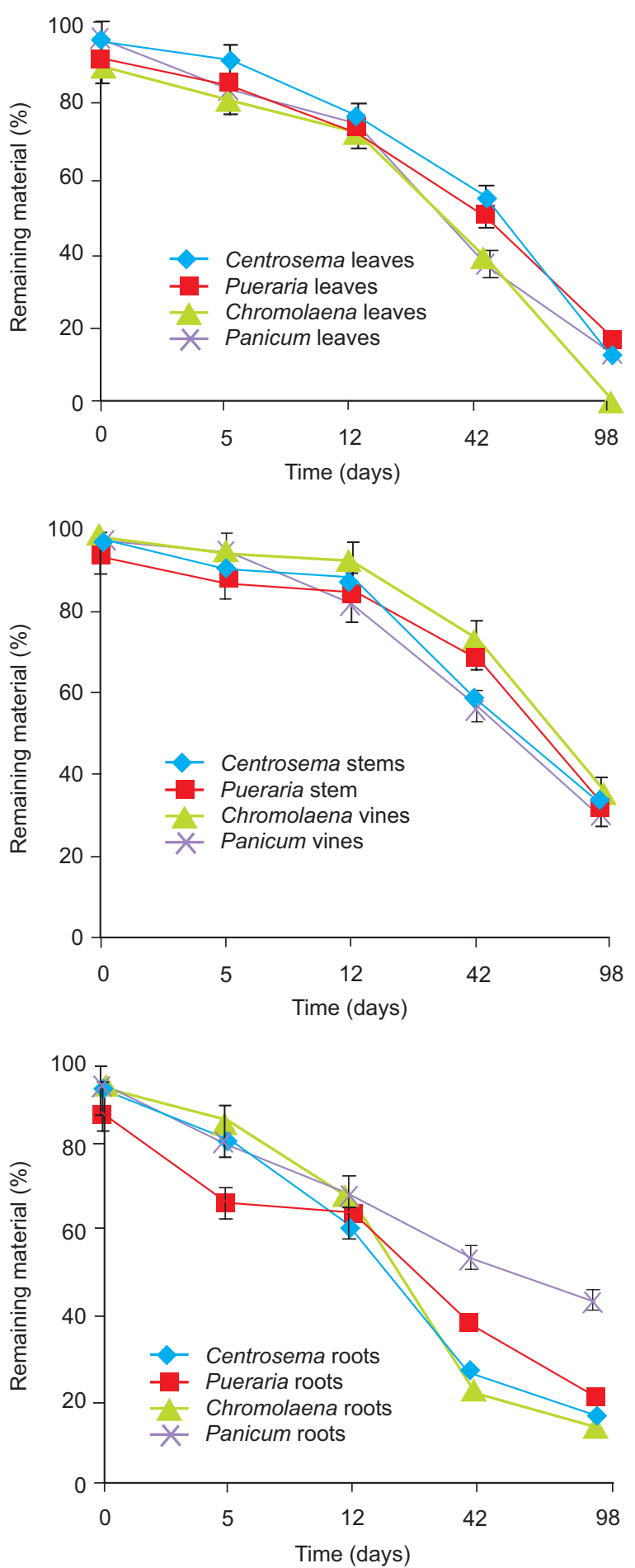

Fig. 1. Dry matter loss in shoots and roots of leguminous and non-leguminous plant species. and $P$. maximum showed a steady net $\mathrm{N}$ mineralization throughout the study period. The pattern of $\mathrm{N}$ remaining in the stems/vines of the species at 98 DAP were in the order P. phaseoloides $(49 \%)>C$. odorata $(42 \%)>$ C. brasilianum $(41 \%)>$ P. maximum $(36 \%)$.
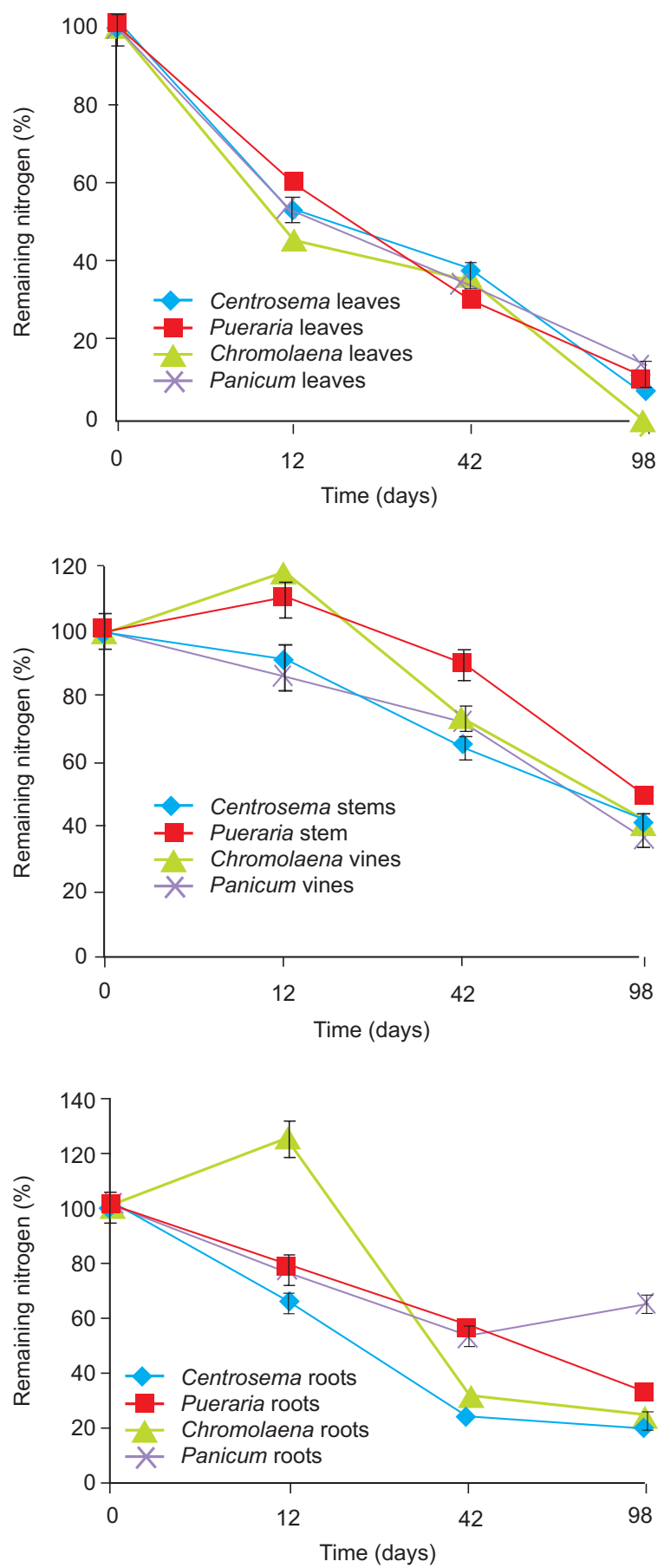

Fig. 2. Nitrogen release pattern in shoots and roots of leguminous and non-leguminous plant species. 
The $\mathrm{N}$ release pattern of the legume roots decreased over time unlike non-leguminous roots. $C$. brasilianum root showed initial $\mathrm{N}$ immobilizations at $12 \mathrm{DAP}$ and then mineralization afterwards. C. brasilianum root released the highest concentration of its $\mathrm{N}$ between $12^{\text {th }}$ and $42^{\text {nd }}$ days of the study. P. maximum root showed an inverse pattern of $\mathrm{N}$ release compared with $C$. brasilianum root. An initial rate of net mineralization was observed up till 42 DAP while immobilization was observed at 98 DAP. The effect of initial cellulose contents of the residues was positively and highly correlated with $\mathrm{N}$ release patterns $(r=0.77, p<0.01)$, but initial $\mathrm{N}$ and $\mathrm{P}$ contents of the residues were inversely related with $\mathrm{N}$ mineralization rates $(r=-0.78 \mathrm{~N}$ and $-0.78 \mathrm{P}, \mathrm{p}<0.01)$ (Table 5).

Phosphorus release pattern. Phosphorus release patterns of different species were significantly different $(p<0.05)$. The pattern of $P$ remaining in the leaves was similar to that of dry matter loss. The percentage $\mathrm{P}$ remaining decreases gradually throughout the decomposition period. Unlike $\mathrm{N}$, less $\mathrm{P}$ were released within the first 12 days of the study (Fig. 3).

For the stem/vines, $\mathrm{P}$ release was more rapid in $C$. brasilianum and $P$. maximum between 12 DAP through 42 DAP. At 42 DAP, $66 \% \mathrm{P}$ and $72 \% \mathrm{P}$ of C. brasilianum and P. maximum had been released respectively. At the end of the study (98 days) significantly higher P remained in the $C$. odorata than other plant species. The $\mathrm{P}$ remaining were in the order; C. odorata $(50 \%)>$ P. phaseoloides $(27 \%)>$ C. brasilianum $(19 \%)>$ P. maximum $(13 \%)$.

$\mathrm{P}$ release pattern of root residues of non-leguminous species was different from that of leguminous species. $\mathrm{P}$ immobilization was observed at $12 \mathrm{DAP}$ for $C$. odorata and at $98 \mathrm{DAP}$ for P. maximum. For the leguminous species, a rapid P mineralization (56\%) was observed in P. phaseoloides root between the first 12 days of decomposition and a gradual mineralization afterwards. Unlike $P$. phaseoloides, C. brasilianum root showed an initial slow P mineralization (17\%) within the first 12 DAP, then gave rapid net $P$ mineralization of $68 \%$ at 42 DAP and followed with gradual release of $\mathrm{P}$ through 98 DAP (Fig. 3). The initial P contents of the residues have a weak inverse relationship with the $\mathrm{P}$ mineralization rates (Table 5).

Soil microbial biomass. There were significant differences $(\mathrm{p}<0.05)$ between the plant species and the parts in their effects on microbial biomass $\mathrm{C}$ and $\mathrm{N}$
(Fig. 4). Biomass $\mathrm{C}$ and $\mathrm{N}$ followed the same pattern for all the treatments since one is a direct measure of the other (Beloso et al., 1993). The inherent microbial $\mathrm{C}$ and $\mathrm{N}$ of the experimental site before the study was higher than what was observed at 12 DAP. The
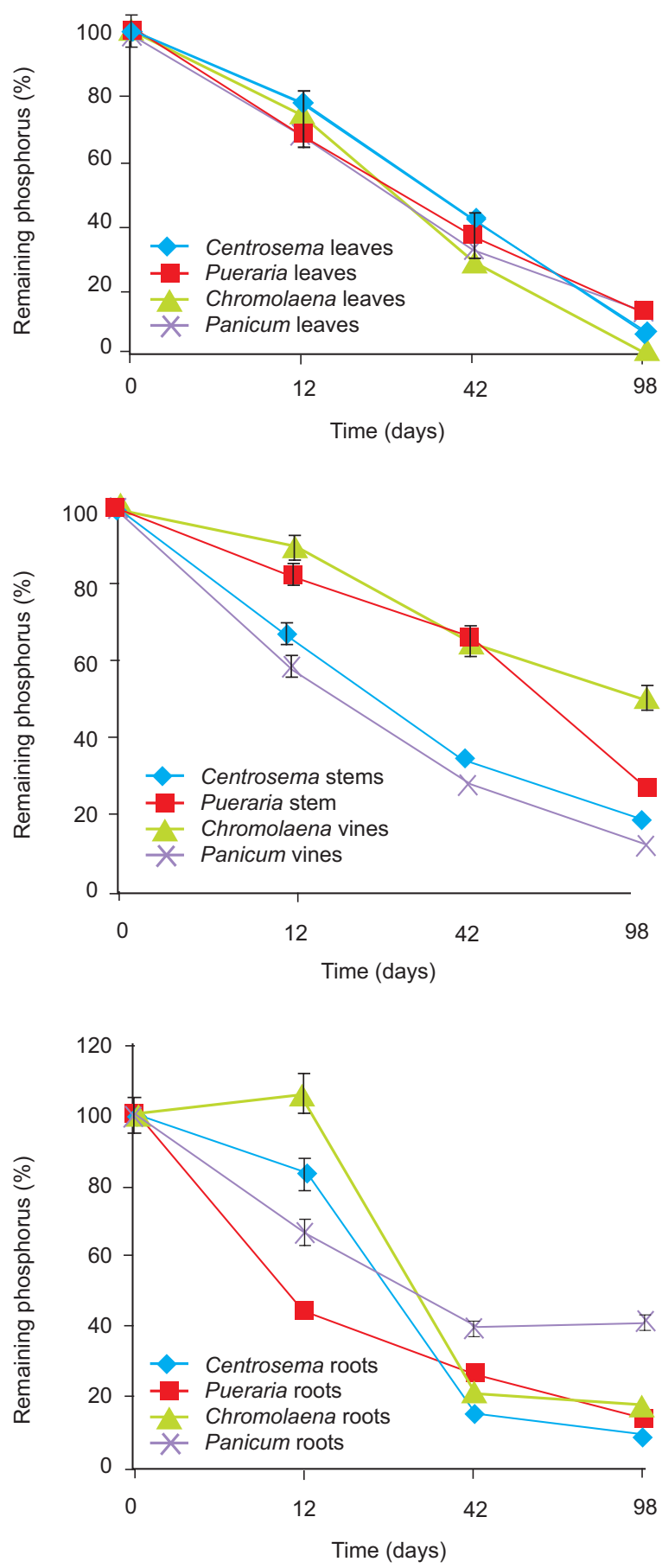

Fig. 3. Phosphorus release pattern in shoots and roots of leguminous and non-leguminous plant species. 
Table 5. Inter correlation $(\mathrm{r})$ among decomposition rate constant $(\mathrm{k})$, residue qualities, nutrient remaining and soil microbial biomass

\begin{tabular}{|c|c|c|c|c|c|c|c|c|}
\hline & $\begin{array}{l}\text { Decomposition } \\
\text { constant }\end{array}$ & Nitrogen & Phosphorus & Polyphenol & Cellulose & $\begin{array}{l}\mathrm{N}- \\
\text { Remaining }\end{array}$ & $\begin{array}{l}\text { P- } \\
\text { Remaining }\end{array}$ & Bio $\mathrm{C}$ \\
\hline Decomposition & - & - & - & - & - & - & - & - \\
\hline constant & - & - & - & - & - & - & - & - \\
\hline Nitrogen & $0.01(\mathrm{~ns})$ & - & - & - & - & - & - & - \\
\hline Phosphorus & $0.03(\mathrm{~ns})$ & $0.89 * *$ & - & - & - & - & - & - \\
\hline Polyphenol & $0.03(\mathrm{~ns})$ & $0.72 * *$ & $0.52(\mathrm{~ns})$ & - & - & - & - & - \\
\hline Cellulose & $-0.15(\mathrm{~ns})$ & $-0.85 * *$ & $-0.69 *$ & $-0.68^{*}$ & - & - & - & - \\
\hline N- Remaining & $-0.4(\mathrm{~ns})$ & $-0.78 * *$ & $-0.78 * *$ & $-0.50(\mathrm{~ns})$ & $0.77 * *$ & - & - & - \\
\hline P- Remaining & $-0.39(\mathrm{~ns})$ & $-0.36 \mathrm{~ns})$ & $-0.53(\mathrm{~ns})$ & $-0.01(\mathrm{~ns})$ & $0.41(\mathrm{~ns})$ & $0.65^{*}$ & - & - \\
\hline Bio $\mathrm{C}$ & $-0.43(\mathrm{~ns})$ & $0.38(\mathrm{~ns})$ & $0.30(\mathrm{~ns})$ & $0.67 *$ & $-0.32(\mathrm{~ns})$ & $-0.19(\mathrm{~ns})$ & $0.12(\mathrm{~ns})$ & - \\
\hline Bio $N$ & $-0.43(\mathrm{~ns})$ & $0.38(\mathrm{~ns})$ & $0.30(\mathrm{~ns})$ & $0.67 *$ & $-0.32(\mathrm{~ns})$ & $-0.19(\mathrm{~ns})$ & $0.12(\mathrm{~ns})$ & $1.00 * *$ \\
\hline
\end{tabular}

** = significant at $1 \% ; *$ significant at $5 \% ; \mathrm{ns}=$ not significant at $1 \%$.

maximum effects of residue input on the microbial biomass $\mathrm{C}$ and $\mathrm{N}$ were observed at $42 \mathrm{DAP}$ for all the parts. The reduction in biomass $\mathrm{C}$ and $\mathrm{N}$ at $98 \mathrm{DAP}$ followed the decrease in dry matter loss of the residues.

Generally, soil microbial biomass $\mathrm{C}$ and $\mathrm{N}$ were higher for the leaves and least for roots except for C. odorata stem, which gave the overall highest biomass $\mathrm{C}$ and $\mathrm{N}$ at 42 DAP. For leaves $P$. phaseoloides had the least biomass $\mathrm{C}$ and $\mathrm{N}$ across the sampling dates. At $42 \mathrm{DAP}$ the biomass $\mathrm{C}$ and $\mathrm{N}$ were in the order $P$. maximum (385 mg C/kg and $57 \mathrm{mg} \mathrm{N} / \mathrm{kg}$ ) $>$ C. odorata (352 mg $\mathrm{C} / \mathrm{kg}$ and $52 \mathrm{mg} \mathrm{N} / \mathrm{kg}$ ) $>$ C. brasilianum $(343 \mathrm{mg} \mathrm{C} / \mathrm{kg}$ and $51 \mathrm{mg} \mathrm{N} / \mathrm{kg})>$ P. phaseoloides $(270 \mathrm{mg} \mathrm{C} / \mathrm{kg}$ and $40 \mathrm{mg} \mathrm{N} / \mathrm{kg}$ ). But at 98 DAP the influence of the plant species on biomass $\mathrm{C}$ and $\mathrm{N}$ were in the order $C$. odorata $>$ P. maximum $>$ C. brasilianum $>$ P. phaseoloides.

For the stems/vines of the species, $P$. phaseoloides also gave the least biomass $\mathrm{C}$ and $\mathrm{N}$ at $12^{\text {th }}$ and 42 DAP while the least was recorded for C. brasilianum at 98 DAP. At 42 DAP, the residues influenced on biomass $\mathrm{C}$ and $\mathrm{N}$ are in the order C. odorata $(430 \mathrm{mg} \mathrm{C} / \mathrm{kg}$ and $63 \mathrm{mg} \mathrm{N} / \mathrm{kg})>$ P. maximum $(387 \mathrm{mg} \mathrm{C} / \mathrm{kg}$ and $57 \mathrm{mg}$ $\mathrm{N} / \mathrm{kg}$ ) $>$ C. brasilianum (297 $\mathrm{mg} \mathrm{C} / \mathrm{kg}$ and $44 \mathrm{mg} \mathrm{N} / \mathrm{kg}$ ) $>$ P. phaseoloides (272 $\mathrm{mg} \mathrm{C} / \mathrm{kg}$ and $40 \mathrm{mg} \mathrm{N} / \mathrm{kg}$ ). At 98 DAP C. odorata stem still gave the highest population of the soil biomass followed by $P$. phaseoloides vine with no distinctive difference between those given by C. brasilianum and P. maximum species.

For the roots at 12 DAP, non-leguminous species supported higher soil biomass $\mathrm{C}$ and $\mathrm{N}$ than the leguminous species with no distinctive difference between each pair of the two classes. At 42 DAP, the residue affected biomass $\mathrm{C}$ and $\mathrm{N}$ in the order of
P. phaseoloides (239 $\mathrm{mg} \mathrm{C} / \mathrm{kg}$ and $35 \mathrm{mg} \mathrm{N} / \mathrm{kg}$ ) > C. odorata (221 $\mathrm{mg} \mathrm{C} \mathrm{kg} \mathrm{and} 33 \mathrm{mg} \mathrm{N} / \mathrm{kg}$ ) $>$ P. maximum (182 $\mathrm{mg} \mathrm{C} / \mathrm{kg}$ and $27 \mathrm{mg} \mathrm{N} / \mathrm{kg}$ ) > C. brasilianum (137 mg C/kg and $20 \mathrm{mg} \mathrm{N} / \mathrm{kg}$ ). At 98 DAP P. maximum root gave slightly higher microbial biomass $\mathrm{C}$ and $\mathrm{N}$ than other three plant species, though with no distinctive difference. Correlation analysis showed that the initial polyphenol contents of the residues had a direct relationship with soil microbial biomass $\mathrm{C}$ and $\mathrm{N}(\mathrm{r}=0.67$, $\mathrm{p}<0.05)$.

The ability of plant residues to decompose and release nutrients is a quality of the plant. For most of the plant species, leaves which are richer in quality than roots and stems/vines built the highest soil nutrients. The implication is that the plant part with highest quality and fastest decomposition rates encouraged higher organic matter build up. This is in agreement with the report that soil organic matter contents and relative proportion of different organic matter fractions, which have different roles in nutrients cycling and in determining soil structure, depend on the amount and quality of organic matter input (Mafongoya et al., 2000; 1998).

The mass loss and decomposition rates of the parts of the plant species followed the initial $\mathrm{N}$ concentrations of the residues in the order of leaves $>$ roots $>$ stems/ vines, which is in agreement with earlier observations of Koenig and Cochran (1994); Rienertsen et al. (1994) and Douglas et al. (1980). C. odorata leaves that had the highest $\mathrm{N}$ content showed the most rapid mass loss while $P$. maximum that had the least $\mathrm{N}$ content had the least mass loss at 98 DAP.

The leguminous plant species on the other hand were intermediate based on their initial $\mathrm{N}$ concentrations. 
Strong correlation between residue $\mathrm{N}$ concentration and $\mathrm{C}$ mineralization suggested that initial $\mathrm{N}$ concentration of residues was the main factor controlling decom-
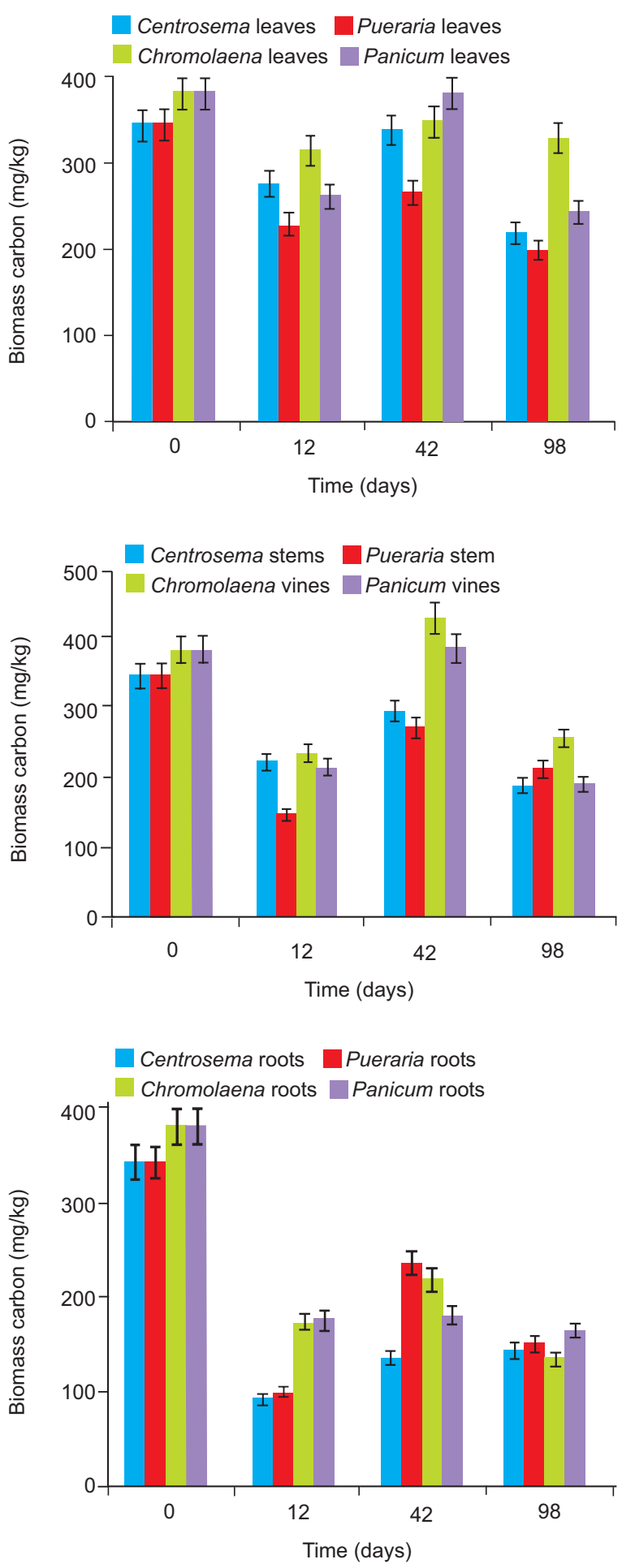

Fig. 4. Microbial biomass $\mathrm{C}$ under shoots and roots of leguminous and non-leguminous plant species. position and nutrient release (Zeng et al., 2010; Teklay et al., 2007; Raiesi, 2006; Mafongoya et al., 2000). The initial concentrations of $\mathrm{N}$, lignin, polyphenol, cellulose and hemicellulose, also belong to some of the chemical factors that influence decomposition rates (Mafongoya et al., 2000; Palm, 1995; Constantinides and Fownes, 1994; Smith, 1994; Tian et al., 1993).

Due to increased plant productivity, trees can also enhance soil fertility by increasing organic matter input through leaf and root decays (Jose et al., 2000). Therefore, legume crops have an advantage over other crops during species selections in temperate agroforestry systems. The lignin content of species determines the mass loss rates of the residues. For non-leguminous species the leaves, stems and roots decomposed in the order of their lignin contents. C. odorata root which had higher lignin decomposed faster than the P. maximum due to its higher $\mathrm{N}$ content. The least decomposition rate constant of $P$. maximum root was due to higher cellulolytic materials in the tissue or some other factors. The lignin content of $P$. phaseoloides leaf and vine was the factor that caused the slow decomposition rate. However, the lower lignin content of the root assisted its faster decomposition rates. For $C$. brasilianum the lignin content also followed the trend in the mass loss and decomposition rates of the parts.

In spite of the higher polyphenol content of $C$. odorata leaf over the leguminous species, it decomposed faster than the corresponding parts in the legumes, this was due to the higher N, low lignin, cellulose and hemicellulose contents in their parts (Hirobe et al., 2005). Although the polyphenol content of the P. maximum leaf was higher than in the stem or root, faster dry matter loss observed in this study was attributed to the higher $\mathrm{N}$ and relatively low lignin content of the leaf (Tian et al., 2007).

The higher the cellulose contents of the plant species, lower the decomposition rate except for the $P$. maximum in which reverse trend was observed. It was so for the P. maximum due to the relatively low lignin contents. The slower decomposition rates observed in the stem/vine compared with leaves and roots of these residues could be attributed to their higher cellulolytic content of the material (Koenig and Cochran, 1994; Rienertsen et al., 1994).

The $\mathrm{P}$ release pattern is similar to $\mathrm{N}$ release pattern in the leaves of the residues except that there was no initial leaching of $\mathrm{P}$ as was the case of $\mathrm{N}$. The lower $\mathrm{P}$ 
mineralization rates observed in the residues could be due to low initial P content in these residues (Gijsman et al., 1997). No P immobilization was observed in the stems/vines but was noticed for roots at 12 DAP in $C$. odorata and at 98 DAP in P. maximum. This observation is due to the amount of soluble $\mathrm{C}$ compounds or little soluble $\mathrm{P}$ in the residues (Mafongoya et al., 1998; Aber and Melillo, 1991) or due to grazing action of fauna on microbial tissues (Tian, 1998; Couteaux and Bottner, 1994). Total P seemed to be a good predictor of rate of residue decomposition. The importance of $\mathrm{P}$ in decomposition had also been observed in other studies (Jin et al., 2008; Liu et al., 2007; Aerts and De Caluwe, 1997).

Application of different plant residues raised the soil microbial biomass $\mathrm{C}$ and $\mathrm{N}$ level that was significant between the plant species. This is a reflection of the increased number of microorganism under the residue (Goyal et al., 1993; Perucci, 1992). The initial decrease in the level of biomass $\mathrm{C}$ and $\mathrm{N}$ recorded at 12 DAP was attributed to degradation of the most biodegradable $\mathrm{C}$ fraction of organic materials by microorganisms (Beloso et al., 1993).

\section{Conclusion}

The quality of the residues used in this study has effect on their decomposition and nutrient release patterns. The decomposition and nutrient release pattern of the root closely followed that of leaf especially in Chromolaena, which was not different from those of legume roots. The roots and leaves had higher effects on the chemical properties of the soil than stems/vines, thus roots may serve as a valuable source of nutrients. The $\mathrm{N}$ release pattern which is correlated with initial cellulose of the residue suggested that cellulose is a predictive factor in $\mathrm{N}$ mineralization of leguminous and non-leguminous plant. Similarly, the polyphenolic content of the residue also enhances the microbial biomass. The data report in this study showed that the decomposition patterns of above and below - ground residues of leguminous and non-leguminous plant species could have positive effect on nutrients requirement of crops. Management techniques that combine different residue parts could be used to manipulate decomposition and nutrients release of organic residues to optimize short and long-term nutrients release patterns to meet crop nutrients requirements.

\section{Acknowledgement}

The authors wish to acknowledge for the facilities provided by International Institute of Tropical Agriculture (IITA), Ibadan, Nigeria. The individual training programme of the IITA allowed the smooth running of the research, especially the training courses.

\section{References}

Aber, J.D., Melillo, J.M. 1991. Terrestrial Ecosystem. 427 pp., Saunder College Publishing of Holt, Rinehart and Winston, Orlando, Florida, USA.

Aerts, R., De Caluwe, H. 1997. Initial litter respiration as indicator for long-term leaf litter decomposition of Carex species. Oikos, 80: 353-361.

Amato, M., Ladd, J.N. 1988. Assay of microbial biomass based on ninhydrin-reactive $\mathrm{N}$ in extracts of fumigated soils. Soil Biology and Biochemistry, 20: 107-114.

Beloso, M.C., Villar, M.C., Cabaneiro, A., Carballas, M., Gonzalez-Prieto, S.S., Carballas, T. 1993. Carbon and nitrogen mineralization in an acid soil fertilized with composed urban refuses. Bioresources Technology, 45: 123-129.

Berg, B., Hannus, K, Popoff, T., Theander, O. 1982. Change in organic chemical components of needle litter during decomposition. Long-term in a Scots pine forest. Canadian Journal of Botany, 60: 13101319.

Berg, B., Staaf, H. 1981. Leaching accumulation and release of nitrogen in decomposing forest litter. In: Terrestrial Nitrogen Cycles. Process, Ecosystem Strategies and Management Impacts. F. E. Clark \& Rosswall (eds.), Ecological Bulletin (Stockholm), 33: 163-178.

Cayuela, M.L., Sinicco, T., Mondini, C. 2009. Mineralization dynamics and biochemical properties during initial decomposition of plant and animal residues in soil. Applied Soil Ecology, 41: 118-127.

Constantinides, M., Fownes, J.H. 1994. Nitrogen mineralization from leaves and litter of tropical plants relationship to $\mathrm{N}$, lignin and soluble polyphenol concentrations. Soil Biology and Biochemistry, 26: 49-55.

Couteaux, M.M., Bottner, P. 1994. Biological interactions between fauna and microbial community in soil. In: Beyond the Biomass, K. Ritz, J. Dighton \& K. E. Giller (eds.), pp. 159-172, John Wiley and Sons Ltd., Chichester, UK.

Douglas, C.L., Allmaras, R.R., Rasmussen, P.E., Ramig, 
R.E., Roager, N.C. 1980. Wheat straw composition and placement effects on decomposition in dryland agriculture of Pacific Northwest. Soil Science Society of American Journal, 44: 833-837.

EMBRAPA. 1999. Manual de Análises Químicas de solos, plantas, e fertilizantes. Empresa Brasilerira de Pesquisa Agropecuária (EMBRAPA), 369 pp., Brasília, DF., Brasil.

Giashuddin, M.M., Garrity, D.P., Aragon, M.L. 1993. Weight loss, nitrogen content changes and nitrogen release during decomposition of legume tree leaves on and in the soil. Nitrogen Fixing Tree Resources and Reproduction, 11: 43-50.

Gijsman, A.J., Oberson, A., Friesen, D.K., Sanz, J.I., Thomas, R.J. 1997. Nitrogen cycling through microbial biomass under rice-pasture rotations replacing native savanna. Soil Biology and Biochemistry, 29: 1433-1441.

Gómez Rey, M.X., Vasconcelos, E., Madeira, M. 2008. Effects of eucalypt residue management on nutrient leaching and soil properties. European Journal of Forest Research, 127: 379-386.

Gosz, J.R., Likens, G.E., Bormann, F.H. 1973. Nutrients release from decomposing leaves and branches litter in the Hubbard Brook forest, New Hampshire. Ecology Monograph, 43: 173-191.

Goyal, S., Mishra, M.M., Dhankar, S.S., Kapoor, K.K., Batra, R. 1993. Microbial biomass turnover and enzymes activities following the application of farmyard manure to field soil with and without previous long-term applications. Biological Fertility of Soils, 15: 60-64.

Hadas, A., Kautsky, L., Goek, M., Kara, E.E. 2004. Rates of decomposition of plant residues and available nitrogen in soil, related to residue composition through simulation of carbon and nitrogen turnover. Soil Biology and Biochemistry, 36: 255-266.

Hirobe, M., Sabang, J., Bhatta, B.K., Takeda, H. 2005. Leaf-litter decomposition of 15 tree species in a lowland tropical rain forest in Sarawak: decomposition rates and initial litter chemistry. Journal of Forest Resources, 9: 341-346.

Hoorens, B., Aerts, R., Stroetenga, M. 2002. Litter quality and interactive effects in litter mixtures: more negative interactions under elevated $\mathrm{CO}_{2}$. Journal of Ecology, 90: 1009-1016.

Jin, J.B., Jin, Y.H., Lee, J., Miura, K., Yoo, C.Y, Kim, W.Y., Van Oosten, M., Hyun, Y., Somers, D.E., Lee, I. 2008. The SUMO E3 ligase, At SIZ1, regulates flowering by controlling a salicylic acidmediated floral promotion pathway and through effects on FLC chromatin structure. Plant Journal, 53: 530-540.

Joergensen, R.G., Brooks, P.C. 1990. Ninhydrin-reactive nitrogen measurement of microbial biomass in $0.5 \mathrm{M} \mathrm{K}_{2} \mathrm{SO}_{4}$ soil extracts. Soil Biology and Biochemistry, 22: 1023-1027.

Jose, S., Gillespie, A.R., Seifert, J.R., Mengel, D.B., Pope, P.E. 2000. Defining competition vectors in a temperate alley cropping system in the midwestern USA. 3. Competition for nitrogen and litter decomposition dynamics. Agroforestry System, 48: 61-77.

Koenig, R.T., Cochran, V.L. 1994. Decomposition and $\mathrm{N}$ mineralization from legume and non-legume crop residues in a sub arctic agricultural soil. Biological Fertility of Soils, 17: 269-275.

Liu, P., Sun, O.J., Huang, J., Li, L., Han, X. 2007. Nonadditive effects of litter mixtures on decomposition and correlation with initial $\mathrm{N}$ and $\mathrm{P}$ concentrations in grassland plant species of Northern China. Biological Fertility of Soils, 44: 211-216.

Mafongoya, P.L., Barak, P., Reed, J.D. 2000. Carbon, nitrogen and phosphorus mineralization of tree leaves and manure. Biological Fertility of Soils, 30: 298-305.

Mafongoya, P.L., Giller, K.E., Palm, C.E. 1998. Decomposition and nitrogen release pattern of tree pruning and litter. Agroforestry System, 38: 77-97.

Mungai, N.W., Motavalli, P.P. 2006. Litter quality effects on soil carbon and nitrogen dynamics in temperate alley cropping systems. Applied Soil Ecology, 31: 32-42.

Myers, R.J.K., Palm, C.A., Cuevas, E., Gunatilleke, I. U.N., Brossard, M. 1994. The synchronisation of nutrients mineralization and plant nutrients demand. In: The Biological Management of Tropical Soil and Fertility. P. L. Woomer \& M. J. Swift (eds.), pp. 81-116, John Wiley and Sons, West Sussex, UK.

Okalebo, J.R., Gathua, K.W., Woomer, P.L. 1993. Laboratory Methods of Soil and Plant Analysis. A Working Manual. TSBF, Nairobi, Kenya.

Palm, C.A. 1995. Contribution of agroforestry tree to nutrients requirements of intercropped plants. Agroforestry System, 30: 105-124.

Parnas, H. 1975. Model for decomposition of organic materials by microorganisms. Soil Biology and Biochemistry, 22: 1023-1027.

Perucci, P. 1992. Enzyme activity and microbial biomass 
in a field soil amended with municipal refuse. Biological Fertility of Soils, 14: 54-60.

Raiesi, F. 2006. Carbon and N mineralization as affected by soil cultivation and crop residue in a calcareous wetland ecosystem in Central Iran. Agricultural Ecosystem and Environment, 112: 13-20.

Rienertsen, S.A., Elliot, L.F., Cochran, V.L. 1994. Role of available carbon and nitrogen in determining the rate of wheat straw decomposition. Soil Biology and Biochemistry, 16: 456-464.

Risasi, E.L., Tian, G., Kang, B.T., Opuwaribo, E.E. 1998. Root decomposition, N release and effect on maize performance. In: Carbon and Nutrients Dynamics in Natural and Agricultural Tropical Ecosystems. L. Bergstrom \& H. Kirchman (eds.), pp. 129-138, CAB International, Wallingford, Oxon, UK.

Sakala, W.D., Cadisch, G., Giller, K.E. 2000. Interactions between residues of maize and pigeon pea and mineral $\mathrm{N}$ fertilizers during decomposition and $\mathrm{N}$ mineralization soil. Soil Biology and Biochemistry, 32: 679-688.

Shen, S.M., Pruden, G., Jenkinson, D.S. 1984. Mineralization and immobilization of nitrogen in fumigated soil and the measurement of microbial biomass nitrogen. Soil Biology and Biochemistry, 16: 437444.

Silver, W.L., Miya, R.K. 2001. Global patterns in root decomposition: comparisons of climate and litter quality effects. Oecologia, 129: 407-419.

Smith, J.L. 1994. Cycling of nitrogen through microbial activity. In: Soil Biology: Effect on Soil Quality. J. L. Hatfield \& B. A. Stewart (eds.), pp. 91-120, Advance in soil sciences CRC press Boca Raton FL, USA.

Swift, M.J., Heal, O.W., Anderson, J.M. 1979. Decomposition in Terrestrial Ecosystems, pp. 1-120,
Blackwell Scientific, Oxford, UK.

Teklay, T., Nordgren, A., Nyberg, G., Malmer, A. 2007. Carbon mineralization of leaves from four Ethiopian agroforestry species under laboratory and field conditions. Applied Soil Ecology, 35: 193-202.

Tian, G., Badejo, M.A., Okoh, A.I., Ishida, F., Kolawole, G.O., Hayashi, Y., Salako, F.K. 2007. Effects of residue quality and climate on plant residue decomposition and nutrient release along the transect from humid forest to Sahel of West Africa. Biogeochemistry, 86: 217-229.

Tian, G., Olimah, J.A., Adeoye, G.O., Kang, B.T. 2000. Regeneration of earthworm populations in degraded soil by natural and planted fallow under tropical humid conditions. Soil Science Society of American Journal, 64: 222-228.

Tian, G. 1998. Effects of soil degradation on leaf decomposition and nutrients release under humid tropical condition. Soil Science, 163: 897-906.

Tian, G., Brussaards, L., Kang, B.T. 1993. Biological effect of plant residues with contrasting chemical composition under humid tropical condition: Effect on soil fauna. Soil Biology and Biochemistry, 25: 731-737.

Van Soest, P.J., Wine, R.H. 1968. Determination of lignin and cellulose in acid detergent fibre with permanganate. Journal of the Association of Agricultural Chemists, 51: 780-785.

Wieder, R.K., Lang, G.E. 1982. A critique of the analytical methods used in examining decomposition data obtained from litterbag. Ecology, 63: 1636-1642.

Zeng, D.H., Rong, M., Scott, X.C., Li, L.J., Yang, D. 2010. Carbon mineralization of tree leaf litter and crop residues from poplar-based agroforestry systems in Northeast China: A laboratory study. Applied Soil Ecology, 44: 133-137. 